\title{
Gambaran Pengelolaan Bersihan Jalan Napas Tidak Efektif pada Anak Dengan Ispa di Desa Kebondowo Banyubiru
}

\author{
Putri Yunanda Pratiwi ${ }^{1}$, Eka Adimayanti ${ }^{2}$ \\ ${ }^{1,2}$ Prodi D3 Keperawatan Fakultas Kesehatan Universitas Ngudi Waluyo \\ Email : Pyunanda276@gmail.com
}

\begin{abstract}
ABSTRAK
Bersihan jalan napas tidak efektif adalah penyakit yang ditandai dengan adanya penumpukkan sekret pada jalan nafas yang menyebabkan ketidakpatenan jalan nafas. Penulisan ini bertujuan untuk memberikan deskripsi atau gambaran tentang pengelolaan bersihan jalan napas tidak efektif pada anak dengan ISPA di Desa Kebondowo Banyubiru. Jenis pengelolaan deskriptif dengan pendekatan studi kasus berupa pengkajian, analisis data, merumuskan diagnosa keperawatan, perencanaan, pelaksanaan, dan evaluasi dalam penanganan bersihan jalan napas tidak efektif. Populasi adalah anak usia toddler dengan bersihan jalan napas tidak efektif. Teknik pengambilan sampel 1 orang. Dengan kriteria anak usia toddler, mengalami batuk pilek, kesadaran composmentis, pasien atau keluarga pasien mampu berkomunikasi secara verbal dan kooperatif. Pengelolaan bersihan jalan napas tidak efektif dilakukan selama 3 hari pada An. A dengan teknik pengumpulan data menggunakan wawancara, pemeriksaan fisik dan observasi. Kemudian dilakukan rencana keperawatan yaitu fisioterapi dada, postural drainage, perkusi, vibrasi. Didapatkan hasil akhir RR: 32x/menit, auskultasi: vesikuler, perkusi: sonor. Berdasarkan tindakan keperawatan yang dilakukan, maka dapat disimpulkan bersihan jalan napas tidak efektif sudah terata. Diharapkan masyarakat atau keluarga pasien selalu menjaga kebersihan dan dapat melakukan tindakan keperawatan infeksi saluran pernafasan akut (ISPA) secara mandiri dan memanfaatkan fasilitas kesehatan untuk berobat.
\end{abstract}

Kata Kunci : Bersihan Jalan Napas, Toddler, Infeksi Pernafasan Akut (ISPA)

\begin{abstract}
Management of Clean Respiratory Is Not Effective In Children With Ari In Kebondowo Village, Banyubiru

Ineffective airway clearance is a disease characterized by a buildup of secretions in the airways that causes airway insufficiency. This writing aims to provide a description or description of the management of ineffective airway clearance in children with ARI in the village of Kebondowo Banyubiru.The type of management is descriptive with a case study approach in the form of assessment, data analysis, formulating nursing diagnoses, planning, implementation, and evaluation in the handling of ineffective airway clearance. The population is toddler age children with ineffective airway clearance. The sampling technique is 1 person. With the criteria of toddler age children, experiencing cough and cold, composmentis awareness, the patient or patient's family is able to communicate verbally and cooperatively.Ineffective airway clearance management was performed for 3 days

Gambaran Pengelolaan Bersihan... Putri Yunanda Pratiwi, Eka Adimayanti Journal of Holistics and Health Sciences Vol. 3, No. 2 September 2021
\end{abstract}


in An. A with data collection techniques using interviews, physical examination and observation. Then the nursing plan is carried out, namely chest physiotherapy, postural drainage, percussion, vibration. The final result was RR: 32x/minute, auscultation: vesicular, percussion: sonor. Based on the nursing actions taken, it can be concluded that the ineffective airway clearance has been resolved. It is expected that the community or patient's family always maintains cleanliness and can carry out nursing actions for acute respiratory infections (ARI) independently and utilize health facilities for treatment.

\section{Keywords: Airway Clearance, Toddler, Acute Respiratory Infection (ARI)}

\section{PENDAHULUAN}

Penyakit ISPA merupakan penyakit mematikan yang sering terjadi pada anak-anak, untuk itu peningkatan pengetahuan pada anggota keluarga sangatlah penting (Sudirman \& Yani, 2019). Menurut Organisasi Kesehatan Dunia Word Health Organization (WHO) ISPA merupakan penyakit saluran pernapasan akut yang disebabkan oleh agen infeksius yang menimbulkan gejala dalam waktu beberapa jam sampai beberapa hari (Maharani, 2017).

Dari data organisasi kesehatan dunia pada tahun 2018 ada kurang lebih 960.000 balita meninggal dunia dan hal tersebut disebabkan oleh ISPA (WHO, 2018). Di Indonesia data prevalensi ISPA menurut provinsi tahun 2018 berdasarkan diagnose tenaga medis dan gejala yang pernah dialami menujukkan bahwa prevalensi tertinggi NTT $(15,4 \%)$, dan terendah Jambi $(5,5 \%)$, sedangkan di Indonesia rata-rata prevalensi pada tahun 2018 adalah 9,3\% (Kemenkes, 2018). Kasus ISPA di Indonesia masih tinggi hasil Riskesdas (Riset Kesahatan Dasar) menunjukkan bahwa prevalensi ISPA tahun 2018 sebesar 4,4\%. Provinsi Jawa Tengah pada tahun 2018 memang bukan termasuk provinsi dengan angka prevalensi
ISPA tertinggi di Indonesia, namun angka ini masih cukup tinggi dan berada di atas angka prevalensi nasional yaitu 4,6\% (Dinas Kesehatan Jawa Tengah, 2018). Prevalensi ISPA di Kabupaten Semarang menurut diagnosa tenaga kesehatan (dokter, perawat atau bidan) adalah 3,31\% dan menurut diagnosis atau gejala yang dialami responden adalah $7,91 \%$ (Dinas Kesehatan, 2018).

Anak yang menderita gangguan pada sistem pernapasan sering mengalami kelebihan produksi lendir di paru-parunya. Dahak atau sputum biasanya akan menumpuk hingga kental dan menjadi sulit untuk dikeluarkan (Aryayuni \& Siregar, 2019). Pengetahuan anggota keluarga mengenai pencegahan penyakit sangat diharapkan, sebab penyakit yang muncul menyerang anggota keluarga bukan hanya dari faktor perilaku namun juga faktor lingkungan seperti kondisi fisik rumah yang harus diperhatikan (Rosiana, 2013). Ketidakefektifan jalan napas merupakan ketidakmampuan dalam mempertahankan bersihan jalan napas dari benda asing yang menyumbat di saluran pernapasan. Terjadi obstruksi pada jalan napas karena menumpuknya dahak atau sputum pada saluran napas yang 
menyebabkan ventilasi menjadi tidak memadai (Tahir et al, 2019).

Fisioterapi dada adalah salah satu penatalaksanaan kebersihan jalan napas, sehingga dari hasil penelitian ini dapat di simpulkan dari beberapa macam penatalaksanaan yang bisa di lakukan untuk kebersihan jalan napas termasuk di dalamnya adalah fisioterapi dada. Dari hasil penelitian Arista, Aminingsih, Endrawati, (2014) tentang pengaruh pemberian fisioterapi dada terhadap kebersihan jalan napas pada pasien ISPA menyebutkan bahwa pemberian fisioterapi dada berpengaruh terhadap kebersihan jalan napas. Dari hasil penelitian Faisal \& Najijah (2019) dengan menggunakan uji statistic Mc Nemar Test tentang clapping dan vibration meningkatkan bersihan jalan nafas pada pasien ISPA didapatkan bahwa clapping dan vibration efektif terhadap bersihan jalan napas dan efektif terhadap tiga dari lima indikator bersihan jalan napas yaitu takipnue (frekuensi napas $>20 x / i)$, sputum dan ronchi. Selain itu terjadi perbaikan terhadap empat dari lima indikator penilaian outcame setelah dilakukan intervensi. Indikator tersebut yaitu dispnue, batuk, frekuensi napas, sputum dan ronchi. Sehingga disimpulkan bahwa clapping dan vibration efektif terhadap bersihan jalan napas pada pasien ISPA. Clapping dan vibration dapat mempertahankan kepatenan jalan nafas dan pelepasan sumbatan sputum pada dinding bronkus.

Menurut penulis tindakan yang efektif untuk mengatasi ketidakefektifan jalan napas dengan ISPA pada pasien usia 14 bulan adalah fisioterapi dada, karena pada usia 16 bulan anak belum bisa mengeluarkan dahak secara mandiri dan harus dibantu oleh orang lain.
Dari hasil penelitian Maidartati, (2014) tentang pengaruh fisioterapi dada terhadap bersihan jalan napas pada anak usia 1-5 tahun yang mengalami gangguan bersihan jalan napas di Puskesmas Moch. Ramdhan Bandung menyebutkan bahwa fisioterapi dada adalah salah satu dari fisioterapi yang menggunakan teknik postural drainase, vibrasi dan perkusi. Fisioterapi dada sangat berguna bagi penderita penyakit respirasi baik yang bersifat akut maupun kronis, dari perpaduan atau kombinasi dari ketiga teknik tersebut sangat bermanfaat untuk mengatasi gangguan bersihan jalan napas terutama pada anak yang belum dapat melakukan batuk efektif secara sempurna. Pada anak yang mengalami gangguan bersihan jalan napas terjadi penumpukan secret dengan adanya tiga teknik tersebut mempermudah pengeluaran secret, secret menjadi lepas dari saluran pernapasan dan akhirnya dapat keluar melalui mulut dengan adanya proses batuk pada saat dilakukan fisioterapi dada.

Selain diberikan terapi untuk mengatasi masalah ISPA, keluarga juga diberikan edukasi tentang penyakit ISPA. Pengendalian penyakit ISPA memerlukan upaya promosi kesehatan untuk meningkatkan upaya kemampuan masyarakat agar hidup sehat dan mampu mengembangkan kesehatan serta terciptanya lingkungan yang kondusif. Peran promosi kesehatan tersebut merupakan tugas bersama antara petugas kesehatan dengan masyarakat (Hapipah dkk, 2021).

\section{METODE}

Metode yang digunakan adalah deskriptif melalui pendekatan dengan pengelolaan asuhan keperawatan yang meliputi 
pengkajian, analisis data, merumuskan diagnosa keperawatan, perencanaan, pelaksanaan, dan evaluasi. Pengelolaan ini dilakukan kepada pasien yang mengalami infeksi saluran pernafasan akut (ISPA) dengan masalah keperawatan yang utama bersihan jalan napas tidak efektif di Desa Kebondowo Banyubiru pada tanggal 1 Februari sampai 3 Februari 2021.

Pengumpulan data yang digunakan adalah menggunakan format pengkajian, proses perijinan melalui surat menyurat dan pengumpulan data menggunakan wawancara, observasi dan pemeriksaan fisik.

Pengambilan sampel pada pengelolaan ini dilakukan dengan cara melakukan observasi dan wawancara dengan bidan desa di Desa Kebondowo Banyubiru, sampel yang di ambil berdasarkan prevalensi di kecamatan Banyibiru pada tahun 2020 terdapat populasi pasien dengan diagnosa ISPA sebanyak 17 orang dengan rincian 8 orang dewasa dan 9 balita. Sampel pada pengelolaan ini adalah seorang balita perempuan berusia 14 bulan yang mengalami batuk pilek sejak 3 hari dan demam sejak bangun tidur. Pengelolaan ini dilakukan dalam waktu 3hari dengan penngambilan data pemeriksaan letak sekret, RR, Suhu tubuh, frekuensi nafas dan pola nafas.

\section{HASIL}

Pengkajian Allowanamnesa dilakukan pada senin 1 Februari 2021 pukul 10.00 WIB di Rumah An. A Desa Kebondowo Banyubiru. Pengambilan data yang dilakukan dengan teknik wawancara dan dokumentasi data di Bidan Sri Harti. Pengambilan data yang dilakukan memerlukan waktu 3 hari.
Analisa data Hasil pengkajian sudah dilakukan dan data yang sudah didapatkan kemudian dilakukan analisa data. Batasan karakteristik pasien yang mengalami bersihan jalan nafas tidak efektif ditandai dengan adanya batuk yang tidak efektif, sputum dalam jumlah yang berlebih, perubahan pola nafas, dyspnea, perubahan frekuensi napas, tidak mampu batuk, mengi, wheeing atau ronki kering, sianoisi, bunyi napas menurun.

Intervensi disusun berdasarkan prioritas masalah yang dialami oleh pasien. Prioritas penanganan pada pasien ISPA dengan masalah keperawatan bersihan jalan napas tidak efektif dilakukan untuk membersihkan sekret atau obstruksi jalan napas untuk mempertahankan jalan napas tetap paten. Tujuan dari intervensi yang disusun yaitu setelah dilakukan tindakan keperawatan selama $3 \times 24$ jam masalah bersihan jalan napas tidak efektif dapat membaik dengan kriteria hasil berpedoman dari bersihan jalan napas (L.01001) yaitu produksi sputum dari nilai 2 (memburuk) menjadi nilai 5 (membaik), wheezing dari nilai 2 (memburuk) menjadi nilai 5 (membaik), frekuensi napas dari nilai 2 (memburuk) menjadi 5 (membaik), pola napas dari nilia 2 (memburuk) menjadi nilai 5 (membaik).

Intervensi yang disusun yaiu fisioterapi dada (I.01004) yang pertama yaiu identifikasi indikasi dilakukan fisioterapi dada. Setelah mengetahui indikasi dilakukannya fisioterapi dada kemudian dilanjutkan intervensi kedua yaitu monitor status pernapasan, dilakukan intervensi tersebut utuk mengetahui frekuensi napas pasien. Setelah mengetahui frekuensi napas pasien kemudia lanjutkan intervensi yang ketiga yaitu 
periksa segmen paru yang mengandung sekresi berlebihan, dilakukan intervensi tersebut untuk mengetahui letak sekret di paru-paru pasien. Setelah mengetahui letak sekret pasien lanjutkan intervensi keempat yaitu posisikan pasien sesuai dengan area paru yang mengalami penumpukan sputum. Setelah di posisikan sesuai penumpukan sputum bisa dilanjutkan intervensi kelima yaitu gunakan bantal untuk pengaturan posisi. Setelah mengatur posisi lanjutkan intervensi yang keenam yaitu lakukan perkusi dengan posisi telapak tangan ditangkupkan selama 3-5 menit, intervensi tersebut dilakukan untuk membantuk mengeluarkan sputum yang menumpuk di paru-paru pasien. Setelah dilakukan perkusi lanjutkan intervensi yang ketujuh yaitu vibrasi dengan telapak tangan rata bersmaan ekpirasi melalui mulut. Setelah sputum berhasil keluar lanjutkan intervensi yang terakhir atau kedelapan yaitu menjelaskan tujuan dan prosedur fisioterapi dada.

Implementasi dilakukan berdasarkan intervensi yang disusun. Implementasi dilakukan dalam 3 kali kelolaan. Hari pertama implementasi dilakukan pada hari Senin, 1 Februari 2021 dimulai pukul 10.30 WIB. Pertama menanyakan indikasi dilakukan fisioterapi dada kemudian mengukur status pernafasan untuk mengetahui RR pasien, setelah itu memeriksa segmen paru yang mengandung penumpukkan sekret dengan menggunakan stetoskop, setelah itu memposisikan pasien kea rah paru yang mengalami penumpukan sekret, lalu melakukan perkusi dengan posisi telapak tangan di tangkup selama 3-5 menit, kemudia melakukan vibrasi dengan telapak tangan rata bersamaan ekspirasi melalui mulut.

Hari kedua implementasi dilakukan pada hari Selasa, 2 Februari 2021 pukul 09.30 WIB yaitu mengukur status pernafasan yang bertujuan untuk mengetahui RR pasien, kemudian memposisikan pasien sesuai dengan area paru yang mengalami penumpukkan sekret, setelah itu melakukan dan menjelaskan tujuan fisioterapi dada, setelah itu menganjurkan inu pasien untuk memberi pasien air hangat atau ASI.

Hari ketiga implementasi dilakukan pada hari Rabu 3, Februari 2021 pukul 09.00 WIB yaitu mengukur status pernafasan apakah ada perubahan dalam status pernafasan, kemudian menganjurkan ibu pasien untuk memberika air hangat saat anak batuk.

Evaluasi dilakukan setelah selesai melakukan tindakan keperawatan. Evaluasi pertama pada hari Senin, 1 Februari 2021 pukul 18.15 WIB dengan respon subyektif ibu pasien mengatakan pasien masih batuk. Respon obyekif yang didapatkan yaitu RR: 38x/menit, N: 125x/menit, auskultasi: ronki, perkusi: ronki: hipersonor. Dari evaluasi tersebut dapat disimpulkan bahwa bersiha jalan napas tidak efektif belum teratasi, sehingga intervensi perlu dilanjutkan diantaranya monitor status pernafasan, periksa segmen paru yang mengandung sekresi berlebihan, posisikan pasien pasien sesuai dengan area paru yang mengalami penumpukkan sputum, lakukan perkusi dengan posisi tangan ditangkupkan 3-5 menit, lakukan vibrasi dengan telapak tangan rata bersamaan ekspirasi melalui mulut.

Evaluasi kedua pada Selasa, 2 Februari 2021 pukul 18.35 WIB 
dengan respon subyektif ibu pasien mengatakan anaknya masih batuk berdahak. Respon obyektif RR: 34x/menit, $\quad \mathrm{N}$ : $125 \mathrm{x} / \mathrm{menit}$, Auskultasi: ronki, perkusi: sonor. Dari evaluasi tersebut dapat disimpulkan bahwa bersihan jalan napas tidak efektif belum teratasi, sehingga intervensi perlu dilanjutkan diantaranya monitor status pernafasan, periksa segmen paru yang mengandung sekresi berlebihan, posisikan pasien pasien sesuai dengan area paru yang mengalami penumpukkan sputum, lakukan perkusi dengan posisi tangan ditangkupkan 3-5 menit, lakukan vibrasi dengan telapak tangan rata bersamaan ekspirasi melalui mulut.

Evaluasi ketiga pada Rabu, 3 Februari 2021 pukul 19.00 WIB dengan respon subyektif ibu pasien mengatakan anaknya sudah tidak batuk berdahak lagi. Respon obyektif yaitu RR; 32x/menit, N: 120x/menit, auskultasi: normal, perkusi: sonor. Dari evaluasi tersebut dapat disimpulkan bersihan jalan napas meningkat sehingga intervensi selanjutnya perlu dipertahankan.

\section{PEMBAHASAN}

Hasil pengkajian sudah dilakukan dan data yang sudah didapatkan kemudian dilakukan analisa data. Pada analisa data ini dikelompokkan menjadi data subyektif dan obyektif. Data subyektif yang didapatkan yaitu ibu pasien mengatakan pasien batuk pilek sejak 3 hari yang lalu, ibu pasien mengatakan pasien susah makan dan minum, ibu pasien mengatakan saat menelan makanan atau minuman pasien menangis kesakitan. Data obyektif yang didapatkan pasien tampak lemas, mukosa bibir lembab dan basah, tampak batuk berdahak, napas tampak cepat, pasien tampak lemas dan rewel, tanda-tanda vital S: $37,4^{\circ} \mathrm{C}, \quad \mathrm{N}: \quad 125 \mathrm{x} / \mathrm{menit}, \quad \mathrm{RR}$ : 38x/menit), Aukultasi: ronki, sekret terletak pada dada sebelah kanan tepat di sinistra, Perkusi: hipersonor. Dari analisa data tersebut kemudia ditegakkan diagnose utama keperawatan yaitu bersihan jalan napas tidak efektif berhubungan dengan sekresi yang tertahan.

Rencana tindakan yang pertama yaitu identifikasi indikasi dilakuka fisioterapi dada. Fisioterapi dada merupakan tindakan melakukan postural drainase, clapping dan vibrating pada pasien dengan gangguan sistem pernafasan utuk meningkatkan efisiensi pola pernapasan dan membersihkan jalan napas (Istichomah, 2020).

Rencana tindakan yang kedua monitor status pernapasan. Pemeriksaan pernafasan meliputi suara nafas, cara bernafas, dan gangguan suara nafas. Tanda-tanda meningkatnya usaha bernafas ditandai dengan retraksi dinding dada, tarikan trakeal, pernafasan cuping hidung, keterlibatan otot dada atau aksesorius, ketidakmampuan berbicara dalam satu kalimat penuh, dan munculnya suara nafas yang terganggu (Wahyuningsih, 2015).

Rencana tindakan yang ketiga Periksa segmen paru yang mengandung sekresi berlebihan. Memeriksa segmen paru untuk mengetahui penumpukkan dengan cara perkusi. Pemeriksaan dengan perkusi dapat dilakukan dengan cara langsung atau tidak langsung. Cara langsung dilakukan dengan mengetukkan ujung jari atau jari telunjuk langsung ke dinding dada, sedangkan cara tidak langsung dengan cara meletakkan satu jari pada dinding dada dan mengentuknya dengan jari tangan lainnya yang 
dimulai dari atas ke bawah serta kanan atau ke kiri dengan membandingkannya (Hidayat, 2013).

Rencana tindakan yang keempat posisikan pasien sesuai dengan area paru yang mengalami penumpukkan sputum. Setelah dilakukan pemeriksaan pasien mengalami penumpukkan sputum pada paru sebelah kanan. Penatalaksanaan fisioterapi dada dengan cara pengaturan posisi untuk membantu pengaliran mukus sehingga segmen besar dengan bantuan gravitasi dan memudahkan mukus untuk diekspektorasikan. Teknik ini dapat dilakukan untuk mencegah terkumpulnya sekret dalam saluran nafas anak dengan sputum yang lebih banyak (Sefriatin, 2015).

Rencana tindakan yang kelima lakukan perkusi dengan posisi telapak tangan ditangkupkan selama 3-5 menit. Clapping atau penepukkan dilakukan dengan menepuk dada posterior dan memberikan getaran (vibrasi) tangan pada daerah tersebut yang dilakukan atau pada saat pasien ekspirasi. Lakukan clapping dengan cara kedua tangan perawat menepuk punggung pasien secara bergantian hingga ada rangsangan batuk (Istichomah, 2020).

Rencana tindakan yang keenam lakukan vibrasi dengan telapak tangan rata bersamaan ekspirasi mulut. Vibrating atau menggetarkan adalah suatu tindakan yang diberikan kepada penderita dengan jalan latihan bernafas, menggetarkan daerah dinding dada. Lakukan vibrating dengan menganjurkan pasien untuk menarik napas dalam dan meminta pasien untuk mengeluarkan napas berlahanlahan (Istichomah, 2020).

Rencana tindakan yang ketujuh jelaskan tujuan prosedur fisioterapi dada. Tujuan fisioterapi mempertahankan ventilasi yang adekuat dan mencegah infeksi, melepaskan dan mengeluarkan sekret dari bronkus dan bronkiolus. Prosedur kerja cuci tangan, lakukan auskultasi pada daerah toraks, lakukan fisioterapi dada: perkusi dan vibrasi (Wijayanti, Paridah \& Lesmana, 2021).

Implementasi pertama yang dilakukan adalah fisioterapi dada. Menurut penulis indikasi dilakukan fisioterapi dada yaitu terdapat penumpukkan sekret pada saluran napas yang dibuktikan dengan pengkajian fisik, X-ray, dan data klinis (Rakhman \& Khodijah, 2014). Dari hasil penelitian Pangesty \& Setyaningrum (2020) tentang penerapan fisioterapi dada terhadap ketidakefektifan jalan nafas pada anak dengan penyakit sistem pernafasan yang menyebutkan bahwa setelah dilakukan tindakan fisioterapi dada, bersihan jalan anak efektif dengan kriteria frekuensi pernafasan dalam batas normal, mampu mengeluarkan sputum, tidak ada suara nafas tambahan, dan batuk berkurang. Teknik fisioterapi dada secara signifikan dapat digunakan untuk mengatasi masalah ketidak efektifan jalan nafas.

Implementasi kedua memonitor status pernapasan. Status pernafasan yang baik adalah nafas tidak ada wheezing dan ronki (Dwienda dkk, 2015). Kebutuhan oksigen merupakan kebutuhan dasar manusia yang digunakan untuk kelangsungan metabolisme sel tubuh mempertahankan hidup dan aktivitas berbagai organ atau sel (Hidayat, 2015).

Implementasi ketiga memeriksa segmen paru yang mengandung sekresi berlebihan. Dari 
pemeriksaan segmen paru pada pasien didapatkan sputum menumpuk pada dada sebelah kanan (Auskultasi: ronki). Ronki basah (rales) / ronki kering mempunyai arti bahwa suara napas, seperti vibrasi terputus-putus yang tidak terus menerus. Hal ini terjadi akibat getaran karena keberadaan cairan dalam nafas yang dilalui oleh udara. Suara ronki kering disebut sebagai rhonchi, merupakan suara terus-menerus yang terjadi karena udara melalui jalan napas yang menyempit akibat proses penyempitan jalan napas atau adanya jalan napas yang obstruksi. Sehinggal lebih terdengar saat ekspirasi daripada inspirasi (Hidayat, 2013). Implementasi keempat memposisikan pasien sesuai dengan area paru yang mengalami penumpukan sputum. Fisioterapi dada meliputi beberapa rangkaian yaitu dengan postural drainase (membaringkan pasien dalam posisi yang sesuai dengan segmen paru yang tersumbat) bertujuan untuk membantu mengalirkan pengeluaran sekresi dengan cara memposisikan pasien berlawanan dengan letak segmen paru yang ada sumbatannya selama 5 menit (Rosyidin, 2013). Berdasarkan jurnal penelitian Sanghati \& Nurhani (2020) menyatakan bahwa adanya postural drainage dapat membantu mengeluarkan sputum pada pasien yang mengalami jalan napas tidak efektif.

$$
\text { Implementasi kelima }
$$

melakukan perkusi dengan posisi telapak tangan ditangkup selama 3-5 menit. Seacara fisiologis perkusi pada permukaan dinding akan mengirimkan gelombang berbagai amplitude dan frekuensi sehingga dapat mengubah kosistensi dan lokasi sekret (Potter dkk, 2017). Dari hasil penelitian Chania \& Andhini (2020) tentang pengaruh teknik perkusi dan vibrasi terhadap pengeluaran sputum pada balita dengan ISPA di Puskesma Indralaya menyatakan bahwa teknik dan vibrasi dapat menjadi penatalaksanaan untuk membantu dan membersihkan jalan nafas dari sputum yang tertahan di dinding dada pada balita dengan ISPA.

Implementasi Keenam melakukan vibrasi dengan telapak tangan rata bersamaan ekspirasi melalui mulut. Teknik vibrasi atau melakukan kompresi dada dengan cara bersamaan dengan batuk efektif, dengan tujuan agar dapat mendorong sekret untuk mudah keluar (Rosyidin, 2013). Dari hasil penelitian Maimuna, Supriyanto \& Bahrudin (2014) tentang efektivitas clapping dan vibrating terhadap kebersihan jalan napas klien dengan ventilasi mekanik yang menyatakan bahwa fisioterapi nafas clapping dan vibrating dapat membantu pengeluaran sekret dari paru-paru atau trakea untuk mempertahankan dan meningkatkan fungsi pernafasan.

Hasil setelah dilakukan pengelolaan selama 3 hari didapatkan hasil masalah keperawatan bersihan jalan napas tidak efektif teratasi. Kondisi tersebut terlihat pada An. A mengalami riwayat ISPA, adanya penumpukan sekret pada paru sebelah kanan, batuk pilek, perubahan frekuensi nafas. Tanda dan gejalanya pasien sudah tidak batuk pilek, tidak batuk berdahak, keluarga pasien sangat kooperatif terutama saat diajarkan fisioterapi dada.

\section{SIMPULAN}

Dalam melakukan asuhan keperawatan pada An. A dengan bersihan jalan napas tidak efektif telah melakukan lima langkah proses 
keperawatan dimulai dari melakukan pengkajian, menetapkan masalah keperawatan, menyusun rencana keperawatan, melakukan implementasi dari rencana yang disusun dan melakukan evaluasi.

Dari lima langkah proses tersebut penulis dapat merumuskan masalah keperawatan yaitu bersihan jalan napas tidak efektif berhubungan dengan sekresi yang tertahan, penulis dapat menyusun rencana keperawatan untuk mengatasi masalah keperawatan dengan fisioterapi dada, penulis dapat mencatat perkembangan pasien setelah dilakukan fisioterapi dada, penulis dapat menyimpulkan evaluasi bahwa bersihan jalan napas tidak efektif sudah teratasi.

\section{SARAN}

Berdasarkan dari pengkajian
hasil pengelolaan Di Desa Kebondowo Banyubiru, maka pengelola bermaksud memberikan saran yang bisa memberikan manfaat bagi lembaga maupun bagi pengelolaan-pengelolaan selanjutnya, sebagai berikut, bagi masyarakat hasil pengelolaan terkait bersihan jalan napas tidak efektif sudah teratasi. Namun secara khusus perlu adanya peningkatan yang lebih baik lagi. Dalam hal ini diharapkan perhatian masyarakat dalam pengelolaan bersihan jalan napas tidak efektif.

\section{DAFTAR PUSTAKA}

Arista, D. Aminingsih, S. Endrawati. (2014). Pengaruh Pemberian Fisioterapi Dada Terhadap Pasien Ispa Di Desa Pucung Eromoko Wonogiri. Di akses pada tanggal 19 Maret 2021.

Aryayuni C, Siregar T. (2019). Pengaruh Fisioterapi Dada Terhadap Pengeluaran
Sputum Pada Anak Dengan Penyakit Gangguan Pernafasaan Di Poli Anak Rsud Kota Depok. Jurnal Keperawatan Profesional Vol. 1 No. 1 November 2020. Di akses pada tanggal 20 Maret 2021.

Chania, Henita., \& Dhona Andhini. (2020). Pengaruh Teknik Perkusi Dan Vibrasi Terhadap Pengeluaran Sputum Pada Balita Dengan ISPA Di Puskesmas Indralaya. Proceeding Seminar Nasional Keperawatan. Vol. 6, No. 1. http://www.conference.unsri. ac.id/index.php/SNK/article/v iew/1727. Di akses pada tanggal 20 Juni 2021

Dinas Kesehatan Jawa Tengah. (2018). Profil Kesehatan Provinsi Jawa Tengah. Semarang. Gambaran Swamedikasi Batuk Anak Di Wilayah Kerja Puskesmas Kabunan Di Kecematan Taman Kabupaten Pemalang. http://www.cyberchmk.net/ojs/index.php/farma si/article/view/863/302

Dwienda, Octa R., Dkk. (2015). Buku Ajar Asuhan Kebidanan Neonatus, Bayil Balita dan Anak Prasekolah Untuk Para Bidan. Deepublish. https://www.google.co.id/boo ks/edition/Buku_Ajar_Asuha n_Kebidanan_Neonatus_Bayi /dKzpCAAAQBAJ?hl=id\&g $\mathrm{bpv}=0$. Di akses pada tanggal 21 Juni 2021

Faisal, A. M., \& Najihah, N. (2019). Clapping dan Vibration Meningkatkan Bersihan Jalan 
Napas pada Pasien ISPA. Jurnal Penelitian Kesehatan "SUARA FORIKES" (Journal of Health Research "Forikes Voice"), 11(1), 77. https://doi.org/10.33846/sf11 116

Hapipah, dkk. (2021). Edukasi Waspada Terkena ISPA Pada Musim Hujan Di Masa Pandemi Di SMP Islam Salafiyah Darul Falah Pagutan Kota Mataram. Lintera Jurnal. Vol. 1, No.1. http://journal.stikesyarsimatar am.ac.id/index.php/lentera/art icle/view/85/23. Di akses pada tanggal 10 Juni 2021

Hidayat, A. A. A. (2013). Pengantar Ilmu Kesehatan Anak untuk Pendidikan Kebidanan. Jakarta: Salemba Medika

Hidayat, A. Alimul Aziz \& Uliah, Musrifatul. 2015. Pengantar Kebutuhan Dasar Manusia Edisi 2- Buku 2. Jakarta: Salemba Medika

Istichomah. (2020). Modul Keperawatan Dasar I. Media Sains Indonesia. https://www.google.co.id/boo ks/edition/Modul_Praktikum_ Keperawatan_Dasar_I/yOYS EAAAQBAJ?hl=id\&gbpv=0. Di akses pada tanggal 21 Juni 2021

Kementerian Kesehatan RI. (2018). Prevalensi ISPA Menurut Provinsi Tahun 2018. Jurnal KESMAS, Vol. 9, No. 7, Desember 2020. Di akses pada tanggal 26 April 2021
Maharani. (2017). Profil Balita Penderita Infeksi Saluran Nafas Akut Atas di Poliklinik Anak RSUP DR. M. Djamil Padang Tahun 2017. Kesehatan Dan Pembangunan, 10(20), 79-88. Di akses pada tanggal 20 Maret 2021.

Maidartati. (2014). Pengaruh Fisioterapi Dada Terhadap Bersihan Jalan Nafas Pada Anak Usia 1-5 Tahun Yang Mengalami Gangguan Bersihan Jalan Nafas Di Puskesmas Moch. Ramdhan Bandung. Ilmu Keperawatan, 2(1), 47-56.

Maimuna, Siti,. Didit Supriyanto, Moch. Bahrudin. (2014). Efektivitas Clapping dan Vibrating Terhadap Kebersihan Jalan Nafas Klien Dengan Ventilasi Mekanik. Jurnal Keperawatan. Vol. 7 , No.2. http://journal.poltekkesdepke s-

sby.ac.id/index.php/KEP/artic le/viewFile/478/397. Di akses pada tanggal 20 Juni 2021

Pangesti, Novia Ari., \& Setyaningrum Riski. (2020). Penerapan Fisioterapi Dada Terhadap Ketidakefektifan Kebersihan Jalan Nafas Pada Anak Dengan Penyakit Sistem Pernafasan. Jurnal Kesehatan. Vol. 15, No.2. http://ojs.stikesmukla.ac.id/in dex.php/motor/article/view/6 3/133. Di akses pada tanggal 19 Juni 2021 
Rosiana, A. M. (2013). "Hubungan Antara Kondisi Fisik Rumah Dengan Kejadian Tuberkulosis Paru," J. Public Health (Bangkok), vol. 2, no. 1, pp. 1-8. Faktor-Faktor Yang Berhubungan Dengan Kejadian Penyakit Ispa Pada Anak Dan Balita. https://doi.org/10.31227/osf.i o/d6pmq. Di akses pada tanggal 20 Maret 2021.

Rosyidin, Kholid. (2013). Prosedur Praktik Keperawatan Jilid I. CV Trans Info Media: Jakarta.

Sanghati \& Nurhani. (2020). Pengaruh Fisioterapi Dada Terhadap Pengeluaran Sekret Pada Pasien Penyakit Paru Obstruksi Kronik Di Balai Besar Kesehatan Paru Masyarakat Makasar. Jurnal Mitrasehat. Vol. 10, No. 1. http://journal.stikmakassar.co m/a/article/view/126. Di akses pada tanggal 20 Juni 2021

Sefriatin. (2015). Kombinasi Fisioterapi Dada dengan Batuk Efektif Terhadap Penurunan Frekuensi Batuk dan Pernafasan Pada Pasien TB Paru di Ruang Cendana RSUD Prof. Dr. Margono Soekarjo. http://repository.ump.ac.id/90 10/2/SEFRIATIN_BAB\%20I .pdf. Di akses pada tanggal 21 Juni 2021

Sudirman, S., \& Yani, A. (2019). Faktor-Faktor Yang Berhubungan Dengan Kejadian Penyakit Ispa Pada Anak Dan Balita. https://doi.org /10.31227/osf.io/d6pmq

Tahir R, amalia D, Muhsina S. (2019). Fisioterapi dada dan batuk efektif sebagai penatalaksanaan

ketidakefektifan bersihan jalan nafas pada pasien TB Paru di RSUD Kota Kendari. Jurnal Keperawatan Profesional Vol. 1 No. 1 November 2020. Di akses pada tanggal 20 Maret 2021.

Wijayanti, Dewi., Paridah., \& Hendy Lesmana. (2021). Modul Praktikum Keperawatan Medikal Bedah I. Penerbit: Adab.

https://www.google.co.id/boo ks/edition/Modul_Praktikum_ Keperawatan_Medikal_Beda/ TdQeEAAAQBAJ?hl=id\&gb $\mathrm{pv}=0$. Di akses pada tanggal 21 Juni 2021

Word Health Organization. (2018). The Top 10 Cause Of Death. Global health etimates. Jurnal KESMAS, Vol. 9, No. 7, Desember 2020. Di akses pada tanggal 26 April 2021 